\title{
SUBURBANIZACJA STREFY PODMIEJSKIEJ LUBLINA
}

\author{
Maria Miczyńska-Kowalska \\ Uniwersytet Przyrodniczy w Lublinie, Wydział Agrobioinżynierii, \\ Katedra Roślin Przemysłowych i Leczniczych, Zakład Socjologii Wsi, \\ Kierownik Zakładu: Maria Miczyńska-Kowalska
}

\begin{abstract}
Słowa klucze: suburbanizacja, strefa podmiejska, rozwój obszarów wiejskich, migracje Key words: sub-urbanisation, suburban zone, rural development, migration

JELcode: Q19, R19

S y n o p s i s. W artykule podjęto problematykę dotyczącą suburbanizacji strefy podmiejskiej na przykładzie gmin przyległych do miasta Lublin: Głuska, Jastkowa, Konopnicy, Niedrzwicy Dużej, Niemiec oraz Wólki. Celem badań było wskazanie specyfiki procesu suburbanizacji i zmian w latach 1995-2017 w strefie podmiejskiej, na przykładzie wymienionych gmin. W opracowaniu uwzględniono wymiar demograficzny i ekonomiczny zmian. Oceny procesu suburbanizacji strefy podmiejskiej Lublina dokonano na podstawie liczby ludności w gminach, zmian w poziomie migracji z miast do gmin ościennych Lublina, liczby osób prowadzących działalność gospodarczą, liczby podmiotów gospodarczych funkcjonujących na terenie gminy, struktury zatrudnienia i liczby mieszkań. W opracowaniu wykorzystano literaturę przedmiotu oraz dostępne statystyki Banku Danych Lokalnych GUS.
\end{abstract}

\section{URBANIZACJA I SUBURANIZACJA}

Urbanizacja jest wielopłaszczyznowym oraz wieloaspektowym procesem społecznoekonomicznym i kulturowo-cywilizacyjnym. Proces urbanizacji jest zróżnicowany, gdyż przebiega w odmiennym tempie w różnych krajach, jak również ma różny charakter. Procesy urbanizacji są odzwierciedlane przez zmiany demograficzne, polityczne, kulturowe, ekonomiczne, społeczne, technologiczne, środowiskowe oraz czynniki i uwarunkowania historyczne [Staszewska 2013].

Współcześnie coraz większą wagę przywiązuje się do wymiaru przestrzennego urbanizacji. Proces urbanizacji w wymiarze przestrzennym zachodzi zarówno na obszarach miejskich, jak i wiejskich. Przyczyn urbanizacji przestrzennej wsi należy szukać w modernizacji życia, w bliskim położeniu od miasta/miast, ograniczaniu funkcji rolniczych oraz w pojawieniu się funkcji pozarolniczych. Przeobrażenia na obszarach wiejskich wiążą się z migracjami stałymi i wahadłowymi mieszkańców. Głównymi miernikami urbanizacji są: charakter i gęstość zabudowy, zmiany w układzie przestrzennym, przeobrażenia morfologii osiedli wiejskich, poziom rozwoju sieci i urządzeń infrastrukturalnych, zjawisko rozdrobnienia pól, zmiana struktury użytkowania ziemi, aktywność budowlana, jakość zasobów mieszkaniowych [Staszewska 2013]. W Polsce przyśpieszona suburbanizacja przypadła na czas po transformacji systemowej [Staszewska 2013]. 
Na określenie urbanizacji wsi podmiejskich stosuje się termin „suburbanizacja”. W literaturze przedmiotu można znaleźć wiele definicji tego pojęcia. Różnice w podejściach wynikają z faktu, że jest to proces złożony i wieloaspektowy. Należy także podkreślić, że na świecie występował on w różnym czasie. Różne też były jego mechanizmy oraz przejawy. W literaturze przedmiotu występuje także określenie „rozproszona suburbanizacja”, w rozumieniu rozlewania się miasta, gdzie zabudowa o charakterze podmiejskim pojawia się punktowo, daleko od miasta centralnego i strefy podmiejskiej i jest to zabudowa nieciągła [Degórska 2017]. Zbigniew Zuziak suburbanizację określa jako proces prowadzący do urbanizacji suburbia, a tym samym w konsekwencji do nowej postaci miasta [Zuziak 2005]. Piotr Lorens suburbanizację dzieli na dwie kategorie: wewnętrzną, polegającą na przemieszczaniu się mieszkańców w poszukiwaniu lepszych warunków mieszkaniowych wewnątrz granic administracyjnych miast, i zewnętrzną - proces związany z utratą przez miasto mieszkańców na rzecz gmin ościennych [Lorens 2005]. Suburbanizacja jest jedną z faz cyklu rozwoju miasta, która związana jest ze zmianą liczby ludności (w większym stopniu wzrasta liczba ludności w strefie podmiejskie niż w rdzeniu miejskim) [Zborowski, Chaberko-Kretowicz 2011]. Zamieszkiwanie w suburbiach charakteryzuje się krótkim dojazdem do pracy. Są one współcześnie ważnym czynnikiem rozwoju obszarów wiejskich. Poprawiają ich atrakcyjność jako miejsca zamieszkania, jak również prowadzenia działalności gospodarczej. Optymalne warunki tworzą równowagę między środowiskiem naturalnym a potrzebami społecznymi i aktywnością społeczną [Czerny 2016]. Pojęcie „suburbia” w literaturze amerykańskiej rozumiane jest jako obszar zamieszkany przez nierolniczą ludność, której egzystencja łączy się z miastem; jest to niemetropolitalny region związany z procesem dekoncentracji ludności miejskiej [Berentsen i inni 2007]. W związku z zachodzącymi procesami urbanizacyjnymi w Stanach Zjednoczonych początkowo „suburbia” związane były z lokalizacją niezamożnej ludności [Kneebone, Garr 2010]. Współcześnie jednak, ze względu na narastającą urbanizację magalopolis, obszary suburbii stają się atrakcyjne dla ludności zamożnej, podobnie jest w Europie. Przyczyny suburbanizacji są różne, m.in. ekonomiczne, społeczne, demograficzne, kulturowe, ekologiczne, psychologiczne, które powodują, że ludność i pomioty gospodarcze przenoszą się na obszary podmiejskie z miast centralnych [Reckien 2014]. W ekonomii neoklasycznej zakłada się, że odległość zamieszkania od centrum jest determinowana uzyskiwanym dochodem, kosztem transportu, korzyściami płynącymi z nowej lokalizacji, m.in. atrakcyjnym otoczeniem, tanim gruntem, dużą przestrzenią, parkingami, etc.

Za początek suburbanizacji w Polsce uważa się przełom XIX/XX wieku, zaś przyśpieszona suburbanizacja przypadła na okres po 1990 roku [Staszewska 2013]. W pierwszym etapie tego procesu następuje przenoszenie budownictwa mieszkaniowego do strefy podmiejskiej, a w kolejnych - przenoszenie budownictwa handlowo-usługowego, przemysłowego i magazynowego. Wskaźnikiem postępującej suburbanizacji są zmiany demograficzne, zwłaszcza dotyczące wzrostu liczby zaludnienia gmin podmiejskich.

Oprócz wskazanych procesów w literaturze przedmiotu można znaleźć jeszcze inne: shrinking cities - „kurczenie się miast”, gated communites - „strzeżone osiedla” czy urban sprawl - „rozlewanie się miast” [Staszewska 2013]. To ostatnie określenie niekiedy stosowane jest jako synonim suburbanizacji. Używane jest przede wszystkim w znaczeniu negatywnego, bezładnego rozrostu miast. Według Europejskiej Agencji Środowiska, urban sprawl jest to uwarunkowany rynkowo fizyczny model ekspansji terenów miejskich o niskiej gęstości na duże obszary, głównie do okolicznych terenów rolniczych 
[Degórska, 2017 s 48]. Zjawisko to ma wiele negatywnych konsekwencji, które można postrzegać z perspektywy społecznej, przestrzennej, gospodarczej, ekologicznej i estetycznej. Skutki społeczne wiążą się z narastającą polaryzacją społeczną, przekształceniami modelu rodziny, segregacją społeczno-ekonomiczną, konfliktami między ludnością autochtoniczna a napływową, zależnością od samochodu i transportu zbiorowego, brakiem dostępu do restauracji, kawiarni, sklepów. Kwestie przestrzenne łączą się z rozprzestrzenieniem zabudowy przy zachowaniu niskiej jej gęstości oraz brakiem infrastruktury drogowej i pieszej. Konsekwencje ekonomiczne wiążą się z wysokim zużyciem wody i energii na 1 mieszkańca, niską wydajnością pracy związaną z długimi dojazdami do pracy oraz zmniejszaniem się obszarów użytkowanych rolniczo. Skutkami ekologicznymi są zmniejszanie się obszarów zieleni przeznaczanych pod zabudowę, ograniczanie bioróżnorodności przyrodniczej oraz zakłócenia rozmnażania się zwierząt. Skutki w aspekcie estetycznym to niszczenie krajobrazu oraz chaotyczna lub monotonna zabudowa [Staszewska 2013].

Kolejne ważne pojęcie to strefa podmiejska. W specjalistycznej literaturze przedmiotu strefę podmiejską określa się jako część miejskiego systemu osadniczego, obszar położony wokót większych miast, powiqzany z miastem funkcjonalnie i przestrzennie [Solarek 2013, s. 7]. Jest on częścią obszaru metropolitalnego. Procesy, które zachodzą w strefach podmiejskich wynikają z rozwoju cywilizacyjnego, w tym postępu technicznego. Tradycyjna funkcja rolnicza stref podmiejskich ulega zmianom. Znikają nierentowne gospodarstwa, natomiast pojawia się produkcja warzyw, owoców i kwiatów. Stare domy zastępowane są nowoczesnymi, typu podmiejskiego lub letniskowego. Zamożna część ludności miasta macierzystego zmienia swoje miejsce zamieszkania. Przenosi się z miasta do strefy podmiejskiej. Obszary o charakterze podmiejskim położone wokół wszystkich polskich miast wykazują szybszy rozwój od obszarów peryferyjnych. Skupiają tym samym większą liczbę ludności. Procesy migracyjne traktuje się jako dobry wskaźnik dla przemian społecznogospodarczych. Przyjmuje się, że ludzie opuszczają miejsca słabiej rozwinięte, o gorszych warunkach życia i przenoszą się w regiony bardziej korzystne [Rosner 2009].

\section{MIGRACJE JAKO ELEMENT URBANIZACJI I SUBURBANIZACJI}

Wraz z rozwojem społeczeństwa przemysłowego na przełomie XIX/XX wieku ludzie najczęściej migrowali ze wsi do miast. Przyczyną było poszukiwanie zatrudnienia w rozwijającym się przemyśle. Ten kierunek utrzymuje się nadal. Ludność z obszarów peryferyjnie wiejskich i mniejszych miast stale wyjeżdża do centrów gospodarczych i edukacyjnych. Ponad 50\% ludności świata zamieszkuje w miastach, a badania prognostyczne pokazują, że tendencje urbanizacyjne w tym zakresie są rosnące [Kosiński 2016]. Jednocześnie w krajach rozwiniętych, również w Polsce, począwszy od lat dziewięćdziesiątych XX wieku coraz bardziej widoczny jest kierunek przeciwny migracji - z miast na wieś.

W warunkach polskich lata dziewięćdziesiąte XX wieku zaznaczyły się wyraźnie w rozwoju strefy podmiejskiej. Mieszkańcy wsi w coraz większym stopniu zaczęli pracować poza rolnictwem. Miasta przestały być jedynymi ośrodkami przemysłowymi. Przemysł zaczął przenosić się bowiem z miast na obszary poza ich granicami, gdzie zaczęły także rozwijać się osiedla mieszkaniowe jednorodzinne, dzielnice-sypialnie oraz obiekty tury- 
styczne i rekreacyjne. Nowo powstałe osiedla nierzadko pozbawione były utwardzonych dróg oraz sieci infrastruktury technicznej. Nie posiadały także ośrodków zdrowia, szkół czy infrastruktury społecznej. Jednak na początku XXI wieku powoli następowało zacieranie różnic między miastem a wsią podmiejską oraz dokonywał się rozwój infrastruktury w strefie podmiejskiej. W ostatnich latach w Polsce utrzymuje się ujemne ogólne saldo migracji dla miast. Jednocześnie odnotowuje się dodatnie dla wsi. Następuje przy tym nasilenie budownictwa mieszkaniowego na wsi. Relacje demograficzne, które należy rozumieć jako migracje występujące między miastem a strefą podmiejską, przebiegają dwukierunkowo. $\mathrm{Z}$ miast migrują jednostki, które są zmęczone życiem miejskim oraz posiadające na to środki finansowe. Do miast przenoszą się zaś m.in. pracownicy, studenci, osoby, które chcą być bliżej centrum. Wskutek zachodzących zmian następuje przemieszanie struktur społecznych, wielozawodowość, większa ruchliwość społeczna oraz zmiana postaw społecznych [Kawczyńska-Butrym 2009]. Migracje nie tylko łączą się ze zmianą miejsca zamieszkania, lecz także z czynnikiem ekonomicznym, np. znalezieniem pracy i uzyskiwaniem wyższych zarobków. Przemieszczenie ze wsi do miasta współcześnie jest utożsamiane także ze zmianą położenia społecznego, z awansem społecznym. Obecnie zmiana miejsca zamieszkania w domu w strefie podmiejskiej, położonej w prestiżowej okolicy jest efektem i dowodem materialnego awansu. Dlatego coraz częściej obserwowana jest tendencja do przenoszenia się bogatej klasy średniej poza granice miast [Kawczyńska-Butrym 2009]. Przez „awans społeczny" należy rozumieć zajmowanie wyższych pozycji społecznych przez jednostki i grupy w strukturze społecznej.

\section{CEL I METODYKA BADAŃ}

W opracowaniu proces suburbanizacji strefy podmiejskiej scharakteryzowano na przykładzie miasta Lublin. Celem badań było wskazanie specyfiki procesu suburbanizacji i określenie zmian zachodzących latach 1995-2017 w gminach przyległych do miasta Lublin. Wskaźnikiem postępującej suburbanizacji są zmiany demograficzne, zwłaszcza dotyczące wzrostu zaludnienia gmin podmiejskich. W związku z tym w opracowaniu zaprezentowano proces migracji w latach 1995-2017. Badaniu także poddano zmiany w liczbie podmiotów gospodarczych na terenie gmin lubelskich: Głuska, Jastkowa, Konopnicy, Niedrzwicy Dużej, Niemiec oraz Wólki. Wskaźniki uwzględnione w opracowaniu dotyczyły: liczby ludności w gminach, zmian w poziomie migracji z miast do gmin ościennych Lublina, liczby osób prowadzących działalność gospodarczą, liczby podmiotów gospodarczych funkcjonujących na terenie gminy, struktury zatrudnienia, liczby mieszkań i powierzchni mieszkań. Wykorzystano metodę analityczno-syntetyczną oraz statystyczną do opracowania danych wtórnych, pochodzących z Banku Danych Lokalnych GUS. Szczegółowo analizowano za lata 1995-2017 zmianę liczby ludności ogółem zamieszkującej gminy ościenne miasta Lublin, liczbę zameldowań z miast w gminach ościennych miasta Lublin, wymeldowania z miasta Lublin na wieś, z kolei aktywność gospodarczą mieszkańców gmin ościennych miasta Lublin analizowano w latach 2002-2017, natomiast za lata 2010-2017 zmianę liczby podmiotów gospodarczych zlokalizowanych na terenie gmin ościennych miasta Lublin, strukturę zatrudnienia według sekcji w gminach ościennych miasta Lublin, a ponadto liczbę mieszkań i średnią powierzchnię mieszkań w gminach ościennych w latach 2008-2017. 


\section{SPECYFIKA GMIN OŚCIENNYCH MIASTA LUBLIN}

W najbliższym sąsiedztwie Lublina znajdują się gminy: Głusk, Jastków, Konopnica, Niedrzwica Duża, Niemce oraz Wólka. Są one ściśle związane z dużym miastem i podlegają intensywnemu procesowi suburbanizacji.

Gmina Głusk stanowi typową podmiejską gminę rolniczą. Grunty orne w gminie, na których przeważa gospodarka indywidualna oparta na gospodarstwach rodzinnych, zajmują 89,03\% powierzchni. Przeważają małe rozdrobnione gospodarstwa. Uprawia się w nich: pszenicę, jęczmień, owies, buraki cukrowe, rzepak i ziemniaki. W okolicach Głuska uprawiane są także warzywa, które są sprzedawane na lubelskim rynku. Do obsługi rynku warzywnego zatrudniana jest ludność autochtoniczna. Liczba instytucji otoczenia rolnictwa wynosi 6 na 1000 mieszkańców. Nie ma jednak zarejestrowanych grup producentów rolnych. Funkcjonuje jedno gospodarstwo nastawione na agroturystykę oraz jedno gospodarstwo, które produkuje żywność ekologiczną. W działalności gospodarczej dominują podmioty z branży usługowej ( $42,9 \%$ ogólnej liczby podmiotów). Inne branże reprezentowane są przez firmy handlowe, usługowo-handlowe, produkcyjno-handlowo-usługowe, produkcyjne, produkcyjno-handlowe oraz podmioty produkcyjno-usługowe. W ostatnich latach liczba podmiotów gospodarczych stale rośnie. W roku 1995 było ich tylko 221. Średni roczny wzrost liczby podmiotów wynosi 20,5\%. Należy podkreślić, że wśród lokalnych przedsiębiorstw na pierwszy plan wysuwa się sektor prywatny [Strategia rozwoju Gminy Gtusk... 2015]. W 2017 roku w rejestrze REGON zarejestrowanych było 1054 podmiotów gospodarki narodowej, saldo migracji ogółem wyniosło 287 osób. Liczba mieszkań oddanych do użytku wyniosła 164, w tym 16 na sprzedaż lub wynajem. W gminie nie ma żłobka, jest 9 placówek wychowania przedszkolnego, 4 szkoły podstawowe, 1 gimnazjum i 4 ośrodki zdrowia. W gminie przypada 815 osób prowadzących działalność gospodarczą na 10000 mieszkańców [Bank Danych Lokalnych, dostęp 23.05.2019].

W gminie Jastków większość mieszkańców zatrudniona jest poza rolnictwem. Rozwija się tu przemysł i usługi. W związku z pozarolniczym charakterem gminy głównym miejscem zatrudnienia dla mieszkańców jest Lublin. Udział osób zatrudnionych poza rolnictwem, jako pracownicy najemni lub przedsiębiorcy, wynosił 19,01\% osób w wieku produkcyjnym. Rolnictwo stanowi podstawowe źródło dochodu tylko dla 9,6\% osób. Pomimo że znaczna część ludności autochtonicznej pracuje w Lublinie, to liczba podmiotów gospodarczych w Jastkowie wzrasta. W latach 2008-2014 wzrost ten wyniósł około 10\%. Liczba podmiotów wpisanych do rejestru REGON na 10 tys. ludności wzrosła z 720 w 2008 r. do 917 w roku 2014. Przeważają mikroprzedsiębiorstwa, które zatrudniają do 9 pracowników. W 2014 r. stanowiły one ponad 97,18\% wszystkich przedsiębiorstw w gminie. Z kolei małe przedsiębiorstwa, zatrudniające od 10 do 49 pracowników, stanowiły 2,41\%, średnie (zatrudnienie od 50 do 249 osób) zaś - 0,39\%. Duże firmy zatrudniające powyżej 250 pracowników stanowiły tylko $0,007 \%$. W gminie zlokalizowane są przede wszystkim przedsiębiorstwa handlowe, prowadzące handel detaliczny i hurtowy. Znajduje się też kilka firm produkcyjnych i usługowych. Korzystają one z nowoczesnych technologii i są nośnikiem innowacji w rozwoju firm w regionie [Strategia rozwoju lokalnego Gminy Jastków ... 2015]. W 2017 roku w rejestrze REGON zarejestrowanych było 1351 podmiotów gospodarki narodowej, saldo migracji ogółem wyniosło 104 osób. Liczba mieszkań oddanych do użytku to 82, w tym 10 na sprzedaż lub wynajem. W gminie nie ma żłobka, jest 9 placówek wychowania przedszkolnego, 
5 szkół podstawowych, nie ma gimnazjów, 5 ośrodków zdrowia. W gminie przypada 814 osób prowadzących działalność gospodarczą na 10000 mieszkańców [Bank Danych Lokalnych, dostęp 23.05.2019].

Gmina Konopnica charakteryzuje się dosyć dużym nasyceniem podmiotami gospodarczymi. Według rejestru REGON, na koniec roku 2014 na terenie gminy zarejestrowanych było 1324 podmiotów gospodarki narodowej, z czego zdecydowaną większość, bo 1115 , stanowiły osoby fizyczne prowadzące działalność gospodarczą. Było to 84,2\% ogółu przedsiębiorców w gminie. Liczba podmiotów gospodarczych plasuje Konopnicę na drugim miejscu wśród gmin i obszarów wiejskich powiatu, tuż za gminą Niemce. W porównaniu z danymi na koniec roku 2006, gdy istniały 792 podmioty, nastąpił przyrost o 532 podmioty, czyli o $67 \%$. W strukturze zatrudnienia mieszkańców gminy dominują przedsiębiorstwa osób fizycznych oraz mikro i małe przedsiębiorstwa - około 97\%. Większość to podmioty sektora prywatnego (99\%). Udział osób fizycznych prowadzących działalność gospodarczą wynosi 84,2\%. W gminie zlokalizowane są: zakłady rzemieślnicze, firmy usługowe z branży budowlanej, handel, gastronomia oraz transport samochodowy. Większość zakładów usługowych i rzemieślniczych świadczy usługi w zakresie produkcji rolniczej i potrzeb bytowych mieszkańców gminy. W związku z atrakcyjną lokalizacją i napływem ludności miejskiej, która chce się osiedlać na terenie gminy, występuje wysokie zapotrzebowanie na usługi z branży budowlanej i wykończeniowej, a także handlu. Należy także podkreślić, że rozwój turystyki weekendowej, głównie podmiejskiej, może przyczynić się do rozwoju usług gastronomicznych, a także nowych dziedzin, niebędących obecnie silną stroną gminy [Strategia rozwoju Gminy Konopnica ... 2016]. W 2017 roku w rejestrze REGON zarejestrowanych było 1470 podmiotów gospodarki narodowej, saldo migracji ogółem wyniosło 183 osoby. Liczba mieszkań oddanych do użytku to 120 . W gminie jest 1 żłobek, 9 placówek wychowania przedszkolnego, 6 szkół podstawowych, 1 gimnazjum, 3 ośrodki zdrowia. W gminie przypada 890 osób prowadzących działalność gospodarczą na 10000 mieszkańców [Bank Danych Lokalnych, dostęp 23.05.2019].

Gmina Niedrzwica Duża nie należy do gmin charakteryzujących się wysokim rozwojem, bowiem funkcjonuje 963 podmiotów gospodarczych. Trend ich powstawania jest obecnie wzrostowy. Działalność gospodarczą prowadzą głównie osoby fizyczne - 86,9\%. Najwięcej podmiotów gospodarczych działa w handlu oraz naprawach - 37,18\%; powyżej 10\% funkcjonuje w sekcji „działalność produkcyjna i obsługa nieruchomości oraz wynajem maszyn". Ważną rolę odgrywają także przedsiębiorstwa z branży budownictwa, transportu i gospodarki magazynowej. W sektorze publicznym działa 5\% jednostek, a $95 \% \mathrm{w}$ prywatnym. Struktura zatrudnienia w tych sektorach wynosiła odpowiednio $39,8 \%$ w publicznym i $60,2 \%$ w prywatnym [Strategia rozwoju Gminy Niedrzwica ... 2008]. W 2017 roku w rejestrze REGON zarejestrowane były 963 podmioty gospodarki narodowej, saldo migracji ogółem wyniosło 61 osób. Liczba mieszkań oddanych do użytku to 46, w tym 4 na sprzedaż lub wynajem. W gminie nie ma żłobka, jest 12 placówek wychowania przedszkolnego, 10 szkół podstawowych, 1 gimnazjum, 5 ośrodków zdrowia. W gminie przypada 641 osób prowadzących działalność gospodarczą na 10000 mieszkańców [Bank Danych Lokalnych, dostęp 23.05.2019].

W gminie Niemce prawie $83 \%$ powierzchni stanowią użytki rolne. Niecałe $6 \%$ to grunty zabudowane i zurbanizowane, a pozostały odsetek to grunty pod wodami, nieużytki i inne tereny. W latach 2009-2013 liczba podmiotów gospodarczych wpisanych 
do rejestru REGON wzrosła z poziomu 1129 do 1520 , wykazując tym samym wzrost na poziomie $34,6 \%$. Są to głównie przedsiębiorstwa z sektora prywatnego. Stanowiły one około 97-98\% ogółu przedsiębiorstw. Dominującą grupą przedsiębiorstw w latach 2009-2014 były mikroprzedsiębiorstwa. W 2014 r. stanowiły około 97\% ogółu podmiotów. Do instytucji otoczenia biznesu, które umożliwiają rozwój przedsiębiorczości na terenie gminy Niemce, można zaliczyć Rynek Elizówka, a także Targowisko Krasienin. Rynek Elizówka to ponadregionalny rynek hurtowy, będący najdalej wysuniętym na wschód rynkiem w Unii Europejskiej. W 2014 r. otwarto nowo wybudowane Targowisko „Mój Rynek” w Krasieninie. Pomimo że użytki rolne stanowią ponad 83\% powierzchni gminy, to spośród 1592 przedsiębiorstw zarejestrowanych w 2014 r. jedynie 22 (1,4\%) działały w sektorze rolnictwa, leśnictwa, łowiectwa i rybactwa. Dominującym profilem działalności przedsiębiorstw w gminie są handel hurtowy i detaliczny, naprawa pojazdów samochodowych [Strategia rozwoju Gminy Niemce ... 2015]. W 2017 roku w rejestrze REGON zarejestrowanych było 1786 podmiotów gospodarki narodowej, saldo migracji ogółem wyniosło 122 osób. Liczba mieszkań oddanych do użytku to 124, w tym 3 na sprzedaż lub wynajem. W gminie jest 1 żłobek, 9 placówek wychowania przedszkolnego, 7 szkół podstawowych, nie ma gimnazjów, 7 ośrodków zdrowia. W gminie przypada 756 osób prowadzących działalność gospodarczą na 10000 mieszkańców [Bank Danych Lokalnych, dostęp 23.05.2019].

Gmina Wólka charakteryzuje się stosunkowo dużym tempem rozwoju ekonomicznego. W roku 1995 liczba przedsiębiorstw w gminie wynosiła bowiem tylko 175, w roku 2000 było ich 295 , a w 2017 roku było ich już 1058 . Przyrost ten należy tłumaczyć przede wszystkim bliskim położeniem względem Lublina. Największą grupę wśród przedsiębiorstw działających w gminie stanowią niewielkie firmy handlowe (zwłaszcza sklepy) i firmy zajmujące się naprawą pojazdów. Oprócz tego istotnymi składnikami struktury ekonomicznej gminy są przedsiębiorstwa realizujące zadania dotyczące budownictwa, obsługi nieruchomości i firm. Dominującą grupę podmiotów gospodarczych stanowią osoby fizyczne prowadzące działalność gospodarczą. W strukturze zatrudnienia mieszkańców gminy dominuje rolnictwo. Występuje także rozdrobnienie pozarolniczej działalności gospodarczej. Według danych statystycznych, w roku $2005 \mathrm{w}$ pozarolniczych przedsiębiorstwach zatrudniających przynajmniej 10 pracowników oraz w sferze budżetowej pracowało łącznie 521 osób. Spośród nich 38 było zatrudnionych w przedsiębiorstwach związanych z rolnictwem, 189 - w firmach przemysłowych, natomiast 294 w usługach; przy czym 219 osób pracowało w tzw. usługach publicznych [Strategia rozwoju Gminy Wólka ... 2007]. W 2017 roku w rejestrze REGON zarejestrowanych było 1058 podmiotów gospodarki narodowej, saldo migracji ogółem wyniosło 214 osób. Liczba mieszkań oddanych do użytku wyniosła 85, w tym 2 na sprzedaż lub wynajem. W gminie jest jeden żłobek, 8 placówek wychowania przedszkolnego, 6 szkół podstawowych, 1 gimnazjum, 7 ośrodków zdrowia. W gminie przypada 714 osób prowadzących działalność gospodarczą na 10000 mieszkańców [Bank Danych Lokalnych, dostęp 23.05.2019].

\section{CHARAKTERYSTYKA STREFY PODMIEJSKIEJ MIASTA LUBLIN}

We wszystkich badanych gminach w latach 1995-2017 następował stały przyrost liczby mieszkańców. Należy zaznaczyć, że proces ten postępuje od początku okresu transformacji systemowej w Polsce (wykres 1.). 


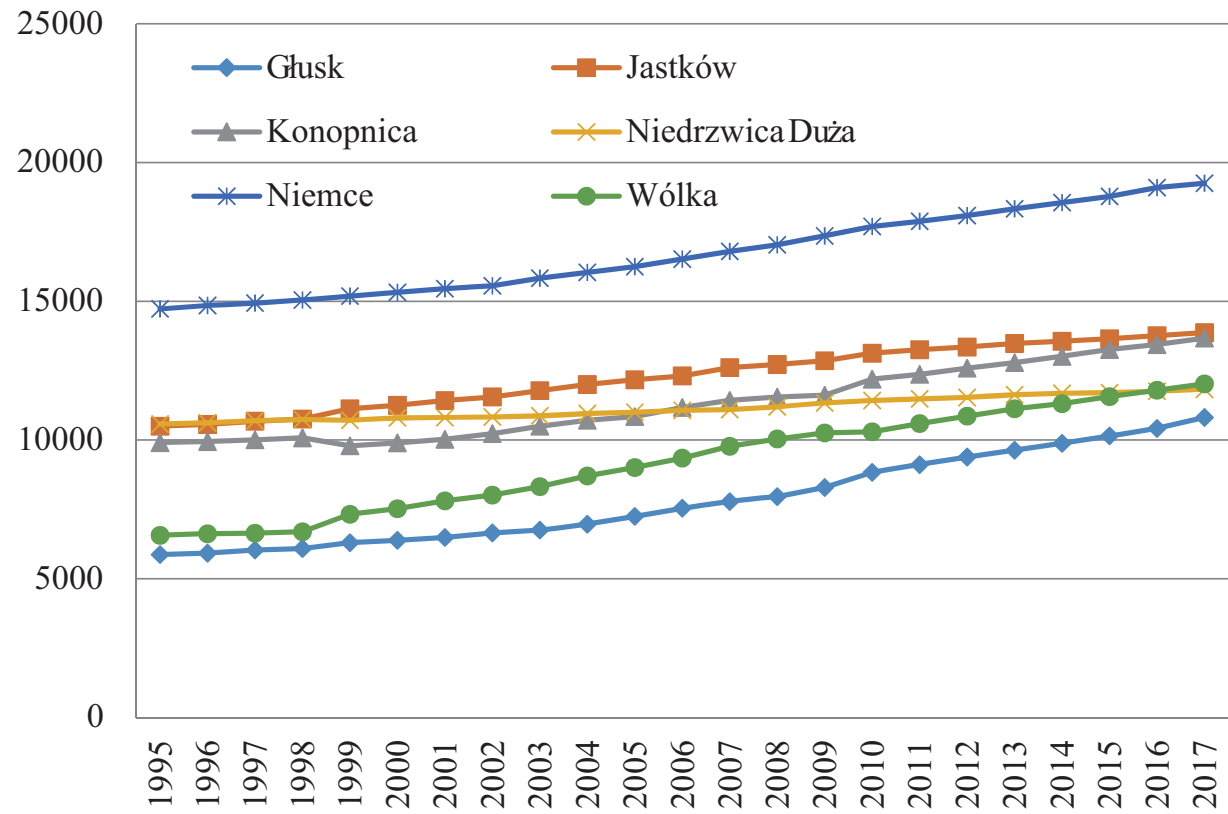

Wykres 1. Ludność ogółem zamieszkująca gminy ościenne aglomeracji lubelskiej w latach 1995-2017

Źródło: opracowanie własne na podstawie Banku Danych Lokalnych GUS.

W latach 1995-2017 tendencja wzrostowa liczby ludności najsilniej występowała w gminach Głusk, Niemce, Konopnica i Wólka, które w strategiach rozwoju zostały scharakteryzowane jako najbardziej nastawione na rozwój przedsiębiorczości. Gmina Jastków, charakteryzowana jako „sypialnia” dla miasta Lublin, charakteryzowała się dynamiką na niższym poziomie. Z kolei gmina Niedrzwica Duża, granicząca z Lublinem na bardzo niewielkim odcinku, scharakteryzowana jako niewyróżniająca się wysokim rozwojem, odznaczała się dynamiką na najniższym poziomie. $Z$ racji położenia nie jest ona atrakcyjna ani biznesowo, ani jako miejsce do osiedlania dla zamożniejszych mieszkańców Lublina, dlatego utrzymuje swój charakter rolniczy.

Dynamikę zmian liczby mieszkańców gmin ościennych miasta Lublin porównano z liczbą migracji z miast do gmin ościennych na podstawie meldunków. Dane na wykresie 2. ukazują przyrost liczby mieszkańców w gminach. Wskazują jednocześnie, że jest to wynik procesu suburbanizacji spowodowany migracjami z miast do strefy podmiejskiej. W gminach Niedrzwica Duża, Wólka i Niemce w 1995 roku poziom migracji z miast utrzymywał się na porównywalnym poziomie: 63 osoby w gminie Głusk, 67 w Niedrzwicy Dużej oraz $63 \mathrm{w}$ Wólce. W kolejnych latach proces migracji znacząco przyśpieszył w gminach Głusk i Wólka. Podobne tendencje występowały w gminach Jastków i Konopnica. W gminie Niedrzwica Duża w całym analizowanym okresie notowano poziom migracji od 57 do 102 osób rocznie.

W 1995 roku wszystkie gminy startowały ze zbliżonego poziomu migracji z miast. Jednak w latach 1995-2017 wielkości te były dosyć wyraźnie zróżnicowane. Największy napływ ludności z miast do gminy odnotowały Niemce, które charakteryzują się wyso- 


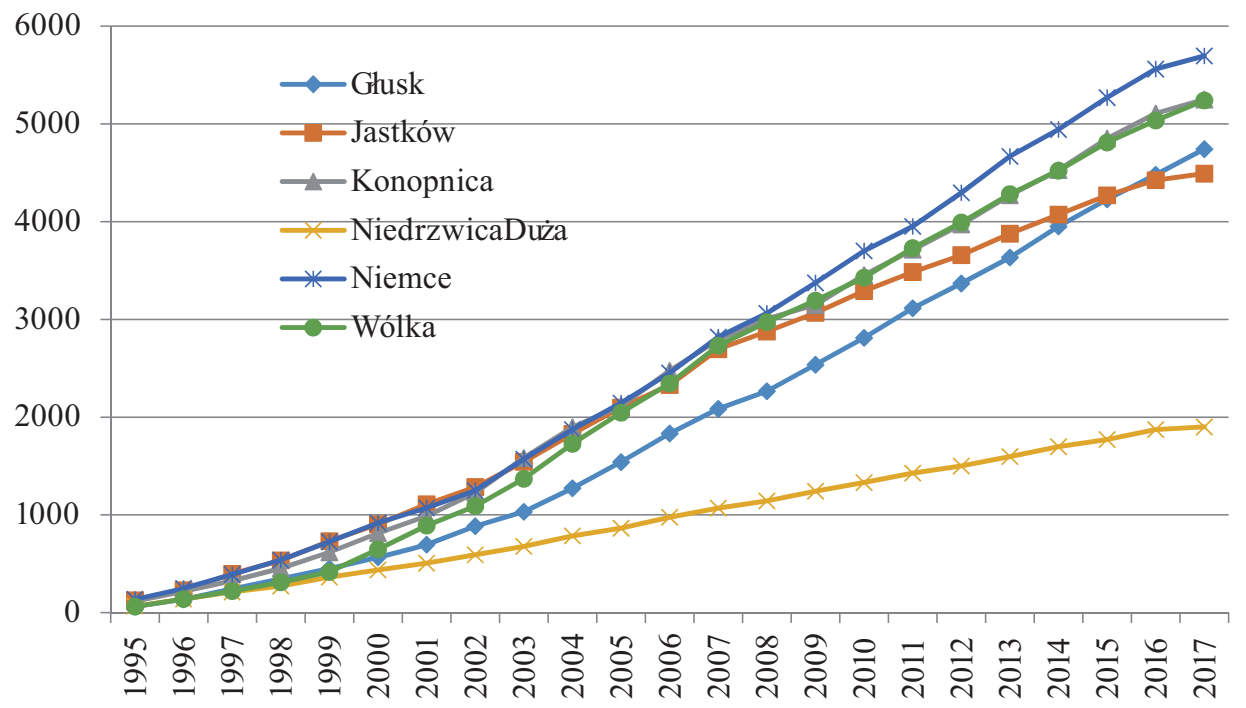

Wykres 2. Zameldowania z miast w gminach ościennych miasta Lublin, wzrost liczby osób migrujących w stosunku do roku poprzedniego (narastająco) [osób rocznie] w latach 1995-2017

Źródło: opracowanie własne na podstawie: Bank Danych Lokalnych GUS

kim potencjałem gospodarczym, co wynika m.in. z lokalizacji na terenie tej gminy giełdy hurtowej. Nieco niższy sumaryczny przyrost migrantów z miast odnotowały gminy Wólka, Konopnica, Głusk i Jastków.

Porównując dane za lata 1995-2017, można wyraźnie wskazać fazy migracyjne z miast do obszarów podmiejskich:

- do roku 2007 dynamika migracji do gmin ościennych była bardzo wysoka, równie szybko „wyludniał” się Lublin;

- w roku 2008 proces migracji wyhamowat;

- w latach 2009-2017 nastąpił dalszy wzrost migracji z miast, które nadal trwają, ale z mniejszą dynamiką, co szczegółowo zaprezentowano w tabeli 1.

Zaprezentowane tendencje migracyjne do gmin podmiejskich można tłumaczyć warunkami makroekonomicznymi występującymi w Polsce w latach 1995-2007. W tym okresie gospodarka rozwijała się prężnie na fali przemian gospodarczych i entuzjazmu wywołanego przejściem od gospodarki centralnie sterowanej do gospodarki rynkowej. Po roku 2007 nastąpił jednak kryzys finansowy, który wstrząsnął gospodarkami krajów zachodnich, również i Polski. Pomimo że Polska z kryzysu wyszła obronną ręką, to - jak wynika $\mathrm{z}$ badań - proces migracji z miast i cały proces suburbanizacji strefy podmiejskiej został trwale spowolniony. Skalę migracji do gmin ościennych i „wyludnianie" miasta Lublin szczegółowo przedstawiono w tabeli 1., która zawiera przyrost liczby mieszkańców w gminach i odpływ mieszkańców Lublina narastająco w stosunku do poprzedniego roku. 


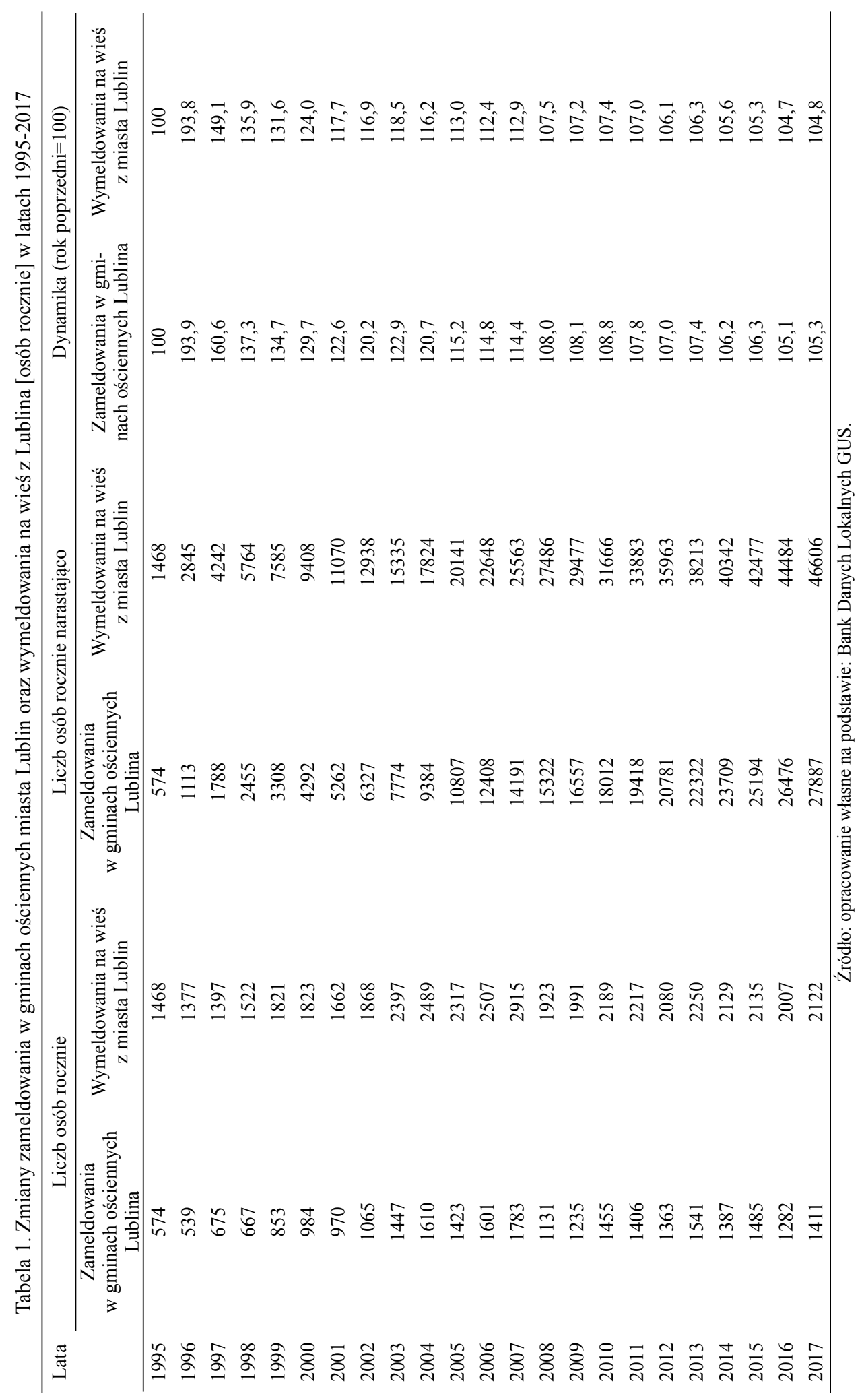




\section{LICZBA PODMIOTÓW GOSPODARCZYCH W STREFIE PODMIEJSKIEJ LUBLINA}

Wraz z procesem napływu ludności miejskiej na tereny podmiejskie wzrosła aktywność gospodarcza mieszkańców gmin. Dostępne dane pochodzące z gmin wskazują wyraźny stały wzrost liczby osób fizycznych zameldowanych w gminach i prowadzących działalność gospodarczą. Suburbanizowane gminy wykazywały się wzrostem aktywności gospodarczej ich mieszkańców (wykres 3.) proporcjonalnym do skali migracji z miast do gmin. Najwyższy poziom aktywności gospodarczej wykazywali mieszkańcy gmin Konopnica, Głusk, Jastków, Niemce i Wólka (w podanej kolejności). Mieszkańcy gminy Niedrzwica Duża byli najmniej aktywni. We wszystkich gminach w latach 2002-2017 następował stały (na porównywalnym poziomie) wzrost liczby osób aktywnych gospodarczo.

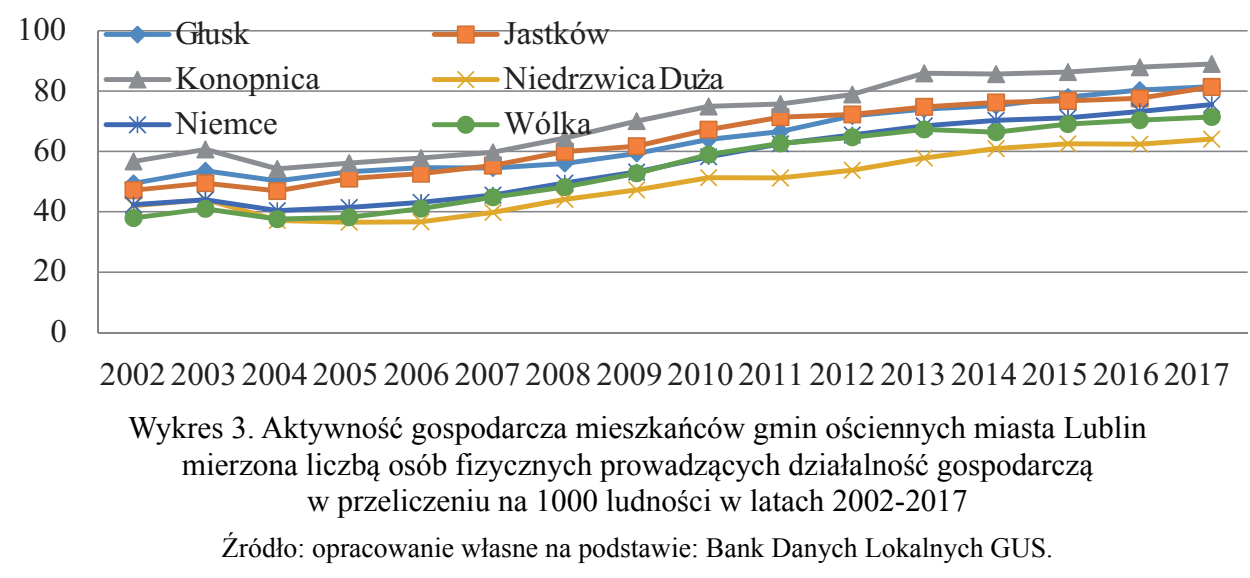

Największa liczba firm była zlokalizowana na terenie gmin Konopnica, Głusk, Niemce, Jastków i Wólka, co szczegółowo zestawiono w tabeli 2. Na ostatnim miejscu znalazła się gmina Niedrzwica Duża. Zestawione dane wskazują tendencję do stałego przyrostu liczby zakładanych firm na terenie analizowanych gmin.

W celu pogłębienia problematyki dotyczącej procesu suburbanizacji strefy podmiejskiej Lublina należy także zwrócić uwagę na zmiany struktury zatrudnienia w latach 2005-2017. Niestety dane w podziale na gminy nie są dostępne, ale dane na poziomie powiatu lubelskiego wydają się wystarczające do zobrazowania tendencji zmian struktury zatrudnienia na terenie gmin powiatu lubelskiego. Dane te wskazują systematyczny spadek odsetka osób zatrudnionych w rolnictwie z 68,5\% w 2005 roku do 63\% w 2017 roku. Sekcja: handel; naprawa pojazdów samochodowych; transport i gospodarka magazynowa; zakwaterowanie i gastronomia; informacja i komunikacja odnotowała dynamiczny wzrost od 5\% w 2005 roku do 9,34\% w 2017 roku. Firmy z tej sekcji na terenie gmin ościennych Lublina rozwijały się najszybciej i w tych regionach powstało ich najwięcej. W pozostałych sekcjach poziom zatrudnienia był stabilny i nie ulegał wyraźnym zmianom [Bank Danych Lokalnych 2019]. 
Tabela 2. Podmioty gospodarcze zlokalizowane na terenie gmin ościennych Lublina na 1000 mieszkańców w latach 2010-2017

\begin{tabular}{lcccccccc}
\hline \multirow{2}{*}{ Gmina } & \multicolumn{7}{c}{ Liczba podmiotów na 1000 mieszkańców w roku } \\
\cline { 2 - 8 } & 2010 & 2011 & 2012 & 2013 & 2014 & 2015 & 2016 & 2017 \\
\hline Głusk & 12,8 & 13,4 & 14,3 & 16,0 & 16,7 & 16,5 & 18,6 & 20,7 \\
Jastków & 13,6 & 15,2 & 14,8 & 15,8 & 16,4 & 16,7 & 18,4 & 19,7 \\
Konopnica & 16,3 & 17,3 & 18,6 & 21,6 & 22,2 & 22,4 & 24,3 & 26,3 \\
Niedrzwica & 9,2 & 9,6 & 9,5 & 10,0 & 10,7 & 12,0 & 12,2 & 13,6 \\
Duża & 13,0 & 14,2 & 14,3 & 15,6 & 16,5 & 17,8 & 18,9 & 19,9 \\
Niemce & 11,5 & 11,9 & 12,7 & 14,5 & 14,9 & 16,7 & 17,0 & 17,3 \\
Wólka & \multicolumn{7}{c}{ Dynamika (rok poprzedni=100) } \\
\hline & 100,0 & 104,7 & 106,6 & 112,0 & 104,5 & 98,5 & 113,2 & 111,2 \\
\hline Głusk & 100,0 & 111,8 & 97,3 & 106,5 & 103,6 & 102,0 & 110,1 & 107,0 \\
Jastków & 100,0 & 106,0 & 107,4 & 116,1 & 102,9 & 100,9 & 108,3 & 108,5 \\
Konopnica & 100,0 & 104,2 & 98,7 & 105,5 & 107,3 & 112,6 & 101,0 & 111,9 \\
Niedrzwica & 100,0 & 109,3 & 100,4 & 109,4 & 105,7 & 108,2 & 106,0 & 105,2 \\
Duża & 100,0 & 106,8 & 113,9 & 103,3 & 111,7 & 102,1 & 101,5 \\
Niemce & 100,0 & 103,8 & 106,8 & \\
Wólka & Źródło: opracowanie własne na podstawie: Bank Danych Lokalnych GUS.
\end{tabular}

\section{LICZBA BUDYNKÓW MIESZKALNYCH NA TERENIE GMIN}

Podstawową miarą procesu urbanizacji danego obszaru jest zmiana liczby mieszkań. Dane dotyczące liczby mieszkań zobrazowano na wykresie 4. Wskazują one wyraźną tendencję wzrostową we wszystkich gminach, a ich dynamika w poszczególnych gminach była zbliżona.

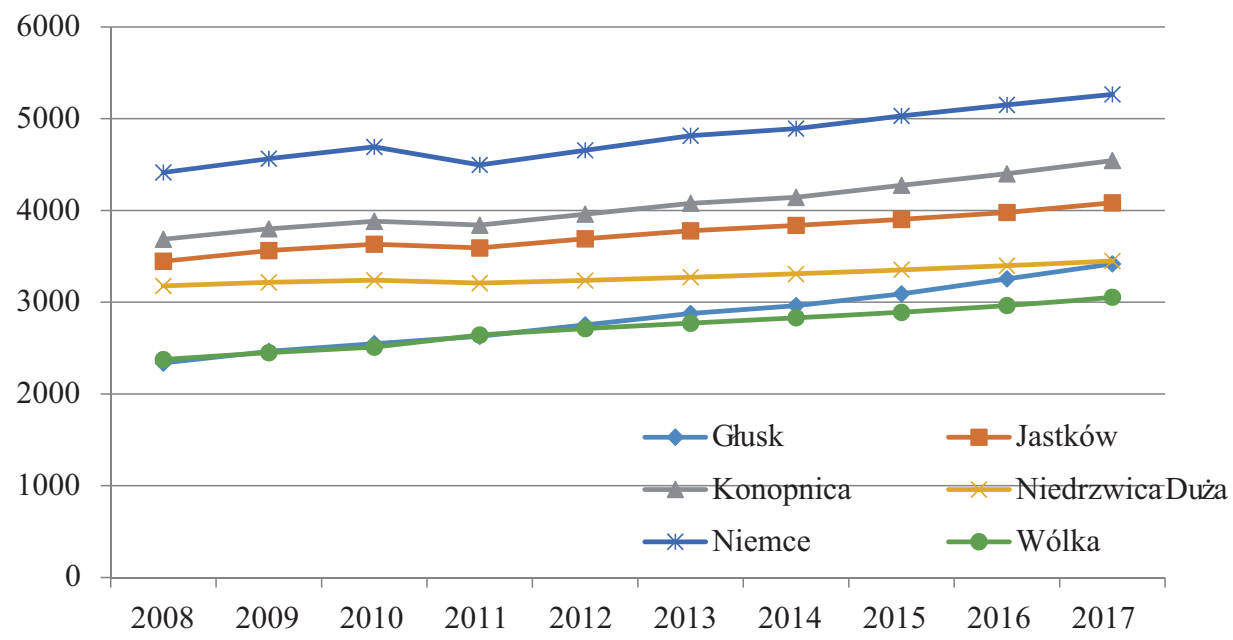

Wykres 4. Liczba mieszkań na terenie gmin w latach 2008-2017

Źródło: opracowanie własne na podstawie Banku Danych Lokalnych GUS. 
Największa liczba budynków mieszkalnych na koniec 2017 roku zlokalizowana była w gminie Niemce i wynosiła 5265, w Konopnicy wyniosła 4544, w Jastkowie - 4083, w Niedrzwicy Dużej - 3450, w Głusku - 3418, a najmniej w gminie Wólka 3054. Cechą charakterystyczną mieszkań budowanych na terenach gmin jest relatywnie wysoka średnia powierzchnia, co pokazuje tabela 3 .

Tabela 3. Średnia powierzchnia mieszkań na terenie gmin w latach 2008-2017

\begin{tabular}{lcccccccccc}
\hline \multirow{2}{*}{ Gmina } & \multicolumn{8}{c}{ Średnia powierzchnia mieszkania w roku $\left[\mathrm{m}^{2}\right]$} \\
\cline { 2 - 10 } & 2008 & 2009 & 2010 & 2011 & 2012 & 2013 & 2014 & 2015 & 2016 & 2017 \\
\hline Głusk & 98 & 101 & 113 & 116 & 117 & 118 & 119 & 121 & 121 & 121 \\
Jastków & 105 & 107 & 110 & 115 & 116 & 116 & 117 & 118 & 118 & 118 \\
Konopnica & 124 & 125 & 112 & 118 & 119 & 120 & 122 & 122 & 121 & 121 \\
Niedrzwica Duża & 98 & 98 & 103 & 106 & 106 & 106 & 107 & 107 & 107 & 108 \\
Niemce & 103 & 105 & 107 & 116 & 117 & 117 & 118 & 118 & 119 & 119 \\
Wólka & 120 & 121 & 125 & 126 & 127 & 128 & 129 & 132 & 131 & 133 \\
\hline
\end{tabular}

Źródło: opracowanie własne na podstawie: Bank Danych Lokalnych GUS.

W analizowanym okresie odnotowano również rosnącą tendencję średniej powierzchni mieszkań, przy czym należy podkreślić, że były to powierzchnie przekraczające $100 \mathrm{~m}^{2}$.

\section{PODSUMOWANIE I WNIOSKI}

W latach 1995-2017 proces suburbanizacji gmin Głusk, Jastków, Konopnica, Niedrzwica Duża, Niemce oraz Wólka dotyczył wielu zmian, w tym demograficznych i ekonomicznych. W analizowanych gminach w badanym okresie wzrosła liczba mieszkańców i odnotowano dodatnie saldo migracji. Wzrosła także liczba podmiotów gospodarczych zarejestrowanych w strefie podmiejskiej, w tym zwiększyła się liczba mieszkańców prowadzących własną działalność gospodarczą. Zmianom uległa struktura zatrudnienia. Budowano także nowe mieszkania. Zdecydowanie zmniejszył się udział osób pracujących w rolnictwie na rzecz zatrudnienia w sekcji: handel; naprawa pojazdów samochodowych; transport i gospodarka magazynowa; zakwaterowanie i gastronomia; informacja i komunikacja. Na podstawie przeprowadzonych badań wykazano, że procesy migracyjne z miast do otaczających je gmin stymulowały rozwój aktywności gospodarczej strefy podmiejskiej, w szczególności stwierdzono:

1. W 1995 roku największą liczbą mieszkańców charakteryzowała się gmina Niemce; kolejne miejsca zajmowały gminy: Niedrzwica Duża, Jastków, Konopnica, Wólka i Głusk. W 2017 roku gmina Niemce utrzymała pierwsze miejsce po względem liczby mieszkańców. Przyrost liczby mieszkańców wyniósł 4529 osób. Gmina Niedrzwica Duża, plasowana na drugim miejscu pod względem liczby mieszkańców w 1995 roku, odnotowała niewielki przyrost liczby mieszkańców. Do 2017 roku przybyło tylko 1255 mieszkańców.

2. W 1995 roku w gminach Głusk, Wólka i Niedrzwica Duża poziom migracji był zbliżony i wynosił odpowiednio 63, 63 i 67 osób migrujących z miast. W gminach Niem- 
ce, Jastków i Konopnica było to 137, 127 i 117 osób migrujących. Największą dynamikę migracji w latach 1995-2017 osiągnęła gmina Niemce, a w dalszej kolejności były Konopnica, Wólka, Głusk, Jastków. W gminie Niedrzwica Duża w tym samym okresie przybyło najmniej migrantów z miast. Największy przyrost liczby mieszkańców we wszystkich gminach odnotowano w latach 2003-2007.

3. We wszystkich badanych gminach następował systematyczny wzrost liczby osób prowadzących działalność gospodarczą. We wszystkich gminach nastąpił także przyrost liczby podmiotów gospodarczych zlokalizowanych na terenie gminy w przeliczeniu na 1000 mieszkańców. W 2017 roku w gminie Konopnica wskaźnik ten wynosił 26,3, Głusk 20,7, Niemce 19,9, Jastków 19,7, Wólka 17,3, Niedrzwica 13,6.

4. Nastąpiła zmiana struktury zatrudnienia. Gminy utrzymały rolniczy charakter, lecz nastąpił spadek liczby i udziału osób zatrudnionych w rolnictwie na korzyść sekcji: handel; naprawa pojazdów samochodowych; transport i gospodarka magazynowa; zakwaterowanie i gastronomia; informacja i komunikacja. Sekcje te są zdominowane przez małe przedsiębiorstwa.

Podsumowując, przeprowadzone badania dotyczące suburbanizacji strefy podmiejskiej Lublina wskazały, że gminy podmiejskie mają dogodne warunki rozwoju. Wykorzystywanie własnego potencjału rozwojowego obszarów podmiejskich uwidacznia się głównie poprzez prowadzenie działalności gospodarczej. Strefę podmiejską Lublina charakteryzują także dogodne warunki zamieszkania, jednak nie wszystkie gminy położone w tej strefie rozwijają się w tym samym kierunku. Badania dowodzą, że we wszystkich zanika funkcja rolnicza.

\section{LITERATURA}

Bank Danych lokalnych GUS, https://bdl.stat.gov.pl/BDL/dane/podgrup/tablica.

Berentsen William, Roosaare Jurii, Samara Paul J. 2007: Suburbanisation and landscape change in Connecticut: Repetition of the patterns in Estonia and Elsewhere in Central Europe, Department of Geography, University of Connecticut Storrs, Connecticut 06269-2148, USA; Institute of Geography, Tartu University, Tartu 51014, Estonia, 2007, s. 2.

Czerny Mirosława 2016: Rozwój zrównoważony obszarów wiejskich na globalnym Południu, Wydawnictwo Uniwersytetu Warszawskiego, Warszawa, s. 25.

Degórska Bożena 2017: Urbanizacja przestrzenna terenów wiejskich na obszarze metropolitalnym Warszawy. Kontekst ekologiczno-krajobrazowy, INVEST-DRUK, Warszawa, s. 44.

Kawczyńska-Butrym Zofia 2009: Migracje. Wybrane zagadnienia, Wyd. UMCS, Lublin, s. 13-14.

Kierunki rozwoju obszarów wiejskich założenia do strategii zrównoważonego rozwoju wsi i rolnictwa Warszawa styczeń 2010, (http://ksow.pl/fileadmin/user_upload/ksow.pl/pliki/rozne_agenda_ itp_/2010.03-KROWaxc.pdf), 22.02.2019.

Kneebone Elizabeth, Garr Emily 2010: The Suburbanization of Poverty: Trends in Metropolitan America, 2000 to 2008, Metropolitan Policy Program at Brookings, Brookings.

Kosiński Wojciech 2016: Paradygmat miasta XXI wieku, Wydawnictwo PK, Kraków, s. 167.

Lorens Piotr 2005: Problem suburbanizacji, Biblioteka Urbanisty, nr 7, Warszawa, s. 19.

Reckien Diana 2014: The social dynamics of suburbanization: insights from a qualitative model, Center for Research on Environmental Decisions (CRED), Columbia University, Columbia, s. 7

Rosner Andrzej 2009: Problem zrównoważonego rozwoju obszarów wiejskich $w$ wymiarze przestrzennym, [w] B. Fiedor Bogusław, Jończy Romuald (red.), Rozwój zrównoważony. Teoria i praktyka ze szczególnym uwzględnieniem obszarów wiejskich, UE we Wrocławiu, Wrocław. 
Solarek Krystyna 2013: Struktura przestrzenna strefy podmiejskiej Warszawy. Determinanty współczesnych przekształceń, Zeszyt Architektura nr 1, Oficyna Wydawnicza Politechniki Warszawskiej, Warszawa, s.7.

Staszewska Sylwia 2013: Urbanizacja przestrzenna strefy podmiejskiej polskiego miasta, Bogucki Wydawnictwo Naukowe, Poznań, s. 18.

Strategia rozwoju Gminy Konopnica na lata 2016-2022, 2016 (http://www.konopnica.eu/ wp-content/ uploads/2016/06/UGK_Strategia_Rozwoju_10_02_2016.pdf), 22.02.2019.

Strategia rozwoju Gminy Niedrzwica Duża na lata 2008-2020, 2008 (http://old.niedrzwicaduza.pl/ UserFiles/File/Strategia/Strategia\%20Rozwoju\%20Gminy\%20Niedrzwica\%20Duza\%20na\% 201.\%202008-2020.pdf), 22.02.2019.

Strategia rozwoju Gminy Niemce na lata 2015-2020, 2015 (https://ugniemce.bip. lubelskie.pl/upload/ pliki//Strategia_Rozwoju_Gminy_Niemce_na_lata_2015-2020.pdf), 22.02.2019.

Strategia rozwoju Gminy Wólka na lata 2007-2020, 2007 (https://docplayer.pl/5064217-Strategia-rozwoju-gminy-wolka-na-lata-2007-2020.html), 22.02.2019.

Strategia rozwoju lokalnego Gminy Jastków na lata 2015-2020, 2015 (https://www.jastkow.pl/ f/23682/2146/Strategia_gminy_Jastk\%C3\%B3w_na_lata_2015-2020-3_dokument_obowi$\%$ C4\%85zuj\%C4\%85cy_.pdf), 22.02.2019.

Strategia rozwoju Gminy Gtusk na lata 2015-2020, 2015 (http://www.glusk.pl/?attachment_id=99), 22.02.2019.

Zborowski Andrzej, Chaberko Tomasz, Kretowicz Paweł 2011: Procesy suburbanizacji rezydencjonalnej w regionie miejskim Krakowa. Przemiany społeczno-przestrzenne, [w] Jakóbczyk-Gryszkiewicz Jolanta (red.) Regiony miejskie w Polsce. Dwadzieścia lat transformacji, Wyd. Uniwersytetu Łódzkiego, Łódź, s. 52-56.

Zuziak Zbigniew 2005: Przestrzenie publiczne - strategie budowania, [w] Gzell Sławomir (red.) Przestrzeń publiczna jako element krystalizacji zespołów urbanistycznych, „Urbanistyka” Międzyuczelniane Zeszyty Naukowe 10/2005, Wydawnictwo Urbanista, Warszawa 2005, s.28-38.

\section{Maria Miczyńska-Kowalska \\ SUBURBANIZATION OF THE SUBURBIAN ZONE OF LUBLIN}

Summary

This issue concerns the suburban zone on the example of municipalities, which are neighbouring the city of Lublin: Gtusk, Jastków, Konopnica, Niedrzwica Duża, Niemce and Wólka. The aim of the analysis to identify the specific characteristics of the suburbanization process and changes in the years 1995-2017 in selected municipalities. The analysis took into account the demographic and economic analysis. The assessment of the suburbanization process of the area of Lublin was based on the analysis of the population in the municipalities, the level of migration from the cities to the neighbouring municipalities of Lublin, the changes in the number of persons carrying on economic activities, the number of traders operating in the municipality, changes of the structure of employment and account of flats. The study uses the literature and available statistics: regional statistics office - Local Data Bank of Central Statistical Office.

Adres do korespondencji:

Dr hab. Maria Miczyńska Kowalska (orcid: 0000-0003-0013-6349)

Uniwersytet Przyrodniczy w Lublinie, Wydział Agrobioinżynierii Katedra Roślin Przemysłowych i Leczniczych, Zakład Socjologii Wsi ul. Akademicka 15 20-950 Lublin e-mail: Maria.Miczynska@up.lublin.pl 